\title{
DAMPAK SENGKETA PULAU DOKDO/TAKESHIMA KOREA SELATAN - JEPANG TERHADAP PERKEMBANGAN HALLYU DI JEPANG
}

\author{
Aldean Tegar Gemilang \\ PT. EVOS E-Sport Indonesia, Jalan R.A Kartini III-S Kav. 06, RT.6/RW.14, Pd. Pinang, Kec. Kby. Lama, Kota \\ Jakarta Selatan, Daerah Khusus Ibukota Jakarta \\ E-mail :deeeaaen@gmail.com
}

\begin{abstract}
This study aims to determine how the impact of the disputed Dokdo Island / Takeshima between South Korea and Japan on the development of Hallyu in Japan Year 2012-2015. The purpose of this study was to determine the impact of the disputed Dokdo / Takeshima between South Korea and Japan on the development of Hallyu in Japan after re-simmering dispute over Dokdo Island / Takeshima by the visit of South Korean President Lee Myung Bak in 2012.

Methods The study was qualitative. Most of the data were collected through interviews, literature study, observation, documentation, and online data searches. The study was conducted at the Korean Cultural Center, The Japan Foundation, Library and Documentation Centre of Scientific Information LIPI, and the Embassy of Japan to Indonesia.

The results showed that the development of Hallyu in Japan after re-simmering dispute over Dokdo Island / Takeshima between South Korea and Japan in 2012 experiencing barriers. Problems island disputes between countries worsen bilateral relations, in the case of disputed Dokdo / Takeshima also have a negative impact on the cultural development of Hallyu in Japan.
\end{abstract}

Keywords: Impact of Dokdo Island Dispute / Takeshima, South Korea and Japan, Hallyu in Japan, development of Hallyu in Japan

\begin{abstract}
Abstrak
Penelitian ini bertujuan untuk mengetahui bagaimana dampak sengketa Pulau Dokdo/Takeshima antara Korea Selatan dan Jepang terhadap perkembangan Hallyu di Jepang Tahun 2012-2015. Tujuan penelitian ini adalah untuk mengetahui dampak sengketa pulau Dokdo/Takeshima antara Korea Selatan dan Jepang terhadap perkembangan Hallyu di Jepang pasca kembali memanasnya sengketa Pulau Dokdo/Takeshima akibat kunjungan Presiden Korea Selatan Lee Myung Bak pada tahun 2012.

Metode Penelitian adalah kualitatif. Sebagian besar data yang dikumpulkan melalui wawancara, studi kepustakaan, observasi, dokumentasi, dan penelusuran data online. Penelitian dilakukan di Korean Cultural Center, The Japan Foundation, Perpustakaan Pusat Dokumentasi dan Informasi Ilmiah LIPI, dan Kedutaan Besar Jepang untuk Indonesia.

Hasil penelitian menunjukan bahwa perkembangan Hallyu di Jepang pasca kembali memanasnya sengketa Pulau Dokdo/Takeshima antara Korea Selatan dan Jepang pada tahun 2012 mengalami hambatan. Permasalahan sengketa pulau antar negara memperburuk hubungan bilateral kedua negara, dalam kasus sengketa pulau Dokdo/Takeshima juga berdampak negatif pada perkembangan budaya Hallyu di Jepang.
\end{abstract}


Kata Kunci: Dampak Sengketa Pulau Dokdo/Takeshima, Korea Selatan dan Jepang, Hallyu di Jepang, Perkembangan Hallyu di Jepang

\section{Pendahuluan}

Perebutan suatu negara terhadap suatu wilayah negara lain sering kali menimbulkan konflik yang berujung pada memburuknya hubungan antara negara yang sama-sama memiliki klaim atas wilayah yang sama.

Sengketa Pulau Dokdo disebut oleh Korea atau disebut juga dengan

Takeshima oleh negara Jepang merupakan isu yang didasari oleh sejarah kolonialisme Jepang terhadap Korea. Jepang mengklaim bahwa pulau Dokdo atau Takeshima tersebut adalah milik Jepang berdasarkan perjanjian yang pernah dilakukan oleh kedua negara pada saat masa kolonialisme.

Dokdo/Takeshima adalah pulau yang terletak kira-kira di pertengahan antara Semenanjung Korea dan Kepulaun Jepang (pada $37^{\circ} 1426,8^{\prime \prime} \mathrm{N}$ dan $131^{\circ} 52$ 10,4” E).Sebenarnya, Dokdo/Takeshima bukan merupakan suatu pulau tapi gugusan pulau. Dokdo/Takeshima terdiri dari dua pulau utama, yaitu Dongdo (Pulau Timur) dan Seodo (Pulau Barat). Kawasan Dongdo adalah $73297 \mathrm{~m}^{2}$, dan Seodo memiliki luas $88639 \mathrm{~m}$ jadi total luas kawasan Dokdo/Takeshima 187.453 m (http://www.dokdo-takeshima.com/).

Penampilan fisik atas Pulau ini sangat mengesankan kedua Negara dan dianggap mencerminkan kepribadian kedua Negara secara simbolik. Sehingga munculah perdebatan kepemilikan atas pulau Dokdo/Takeshima yang mencakup batas-batas kewilayahan secara maritim termasuk penggunaan dan pemanfaatan sumber daya laut yang ada di dalamnya.
Salah satu alasan Korea Selatan mengklaim bahwa Pulau Dokdo/Takeshima berada di bawah kedaulatannya berdasar pada acuan historis yang dikutip dalam beberapa dokumentasi pemerintah Korea Selatan, yang menyatakan bahwa pulau Dokdo/Takeshima pada awalnya merupakan suatu independent island yang dinamakan Ussankuk dan telah bersatu dengan Korea Selatan pada masa Dinasti Shilla pada tahun 512 SM.

Setelah Jepang menyerah kepada sekutu pada tahun 1945, secara otomatis wilayah yang dulu menjadi wilayah jajahan Jepang dikembalikan kepada negara/wilayah yang berkuasa sebelumnya.

$\begin{array}{rrr}\text { Wilayah } & \text { Dokdo atau } & \text { Takeshima } \\ \text { merupakan } & \text { wilayah } & \text { yang }\end{array}$ dipersengkatakan oleh Korea Selatan karena kepemilikannya. Berdasarkan pada perjanjian San Fransisco, kepulauan Dokdo atau Takeshima tidak termasuk kedalam wilayah yang harus dikembalikan oleh Jepang. Pada pasal 2

perjanjian San Fransisco hanya dibicarakan pengembalian wilayah Pulau Kuril dan Senkaku pada Rusia. Hal ini dapat diartikan sebagai legalitas Jepang untuk memiliki pulau Dokdo/Takeshima (Diakses tanggal 14 Maret 2015 melalui

http://world.kbs.co.kr/indonesian/archive/ program/news_zoom.htm?no=4370\&curr ent_page $=15$ ).

Dikatakan didalamnya bahwa: kedua negara akan mengakui adanya klaim satu sama lain atas pulau yang bersangkutan; mendengarkan argumen satu sama lain; akan menyelesaikan permasalahan ini di 
masa yang akan datang; Untuk wilayah Zona Ekonomi Eksklusif (ZEE), kedua negara dapat menggunakan pulau

Dokdo/Takeshima untuk menandai wilayah mereka sementara wilayah yang tumpang tindih akan dianggap sebagai wilayah gabungan; (Philip,2013:5).

Pada setiap tanggal 2 Februari dirayakan hari Takeshima oleh Jepang, Takeshima merupakan sebutan Jepang untuk pulau Dokdo/Takeshima. Secara historis, kepulauan Takeshima merupakan wilayah kedaulatan Jepang, hal ini dibuktikan dengan masuknya Takeshima dalam kedaulatan Jepang sejak masa Edo sekitar tahun 1603 - 1868 (Diakses tanggal 14 Maret 2015 melalui http://www.dokdotakeshima.com/japansmofas propaganda-brochure.html).

Gelombang Korea atau yang lebih dikenal dengan istilah Korean Wave atau juga biasa disebut dengan Hallyu Wave merupakan istilah yang begitu akrab di telinga masyarakat internasional. Hanriu dalam bahasa China atau yang kerap disebut Hallyu dalam bahasa Korea yang pertama kali dimunculkan oleh seorang jurnalis China saat menuliskan maraknya minat akan Korea Selatan beserta produkproduknya di China pada pertengahan tahun 1999 (Korean Culture and Information Service,2011;20-21).

Korean Hallyu merupakan sebuah istilah yang dikeluarkan oleh Korea Selatan untuk mendeskripsikan tentang kebudayaan Korea Selatan yang berhasil di ekspor ke berbagai negara di duni a (Diakses tanggal 15 Maret 2015 melalui http://www.korea.net/Government/Curre nt-Affairs/Korean-Wave?affairId=209). Mesin penggerak dari Korean Hallyu ini sendiri merupakan musik, film, drama, sektor pariwisata, makanan, kebudayaan tradisional dan modern, serta pemasaran produk-produk komersial yang berasal dari Korea Selatan. Sama halnya di Jepang, kepopuleran Hallyu diawali dengan ditayangkannya serial drama Winter Sonata atau disebut Gyeoul Yeonga dalam bahasa Korea pada tahun 2003. 12 Drama serial Winter Sonata pertama kali disiarkan di Jepang melalui stasiun televisi NHK ( Nippon Hoso Kyokai), disiarkan dengan menggunakan bahasa Korea dan Hallyu dimanfaatkan oleh pemerintah Korea Selatan untuk melakukan diplomasi budaya di seluruh dunia. Diplomasi merupakan instrumen soft power dari politik luar negeri dan digunakan untuk mencapai kepentingan nasional suatu negara.

\subsection{Rumusan Masalah}

Berdasarkan klaim kedua Negara tersebut diatas, dan pengaruhnya terhadap Hallyu Wave di Jepang maka peneliti tertarik untuk mengkaji, mencermati, dan mempelajari fenomena tersebut sebagai bahan penelitian dengan mendeskripsikannya melalui judul: "Pengaruh Sengketa Pulau Dokdo / Takeshima Korea Selatan-Jepang Terhadap Perkembangan Hallyu Di Jepang”.

\subsection{Maksud dan Tujuan \\ 1.3.1 Maksud Penelitian}

Penelitian ini dimaksudkan untuk mengetahui bagaimana dampak sengketa Pulau Dokdo/Takeshima antara Korea Selatan dan Jepang terhadap perkembangan Hallyu di Jepang.

\subsubsection{Tujuan Penelitian}

a) Untuk mengetahui bagaimana perkembangan Hallyu di Jepang pasca kembali memanasnya sengketa Pulau Dokdo/Takeshima 
antara Korea Selatan dan Jepang pada tahun 2012

b) Untuk mengetahui apa saja hambatan terhadap perkembangan Hallyu di Jepang.

c) Untuk mengetahui Bagaimana perkembangan dan prospek Hallyu di Jepang kedepannya

\subsection{Kegunaan Penelitian}

\subsubsection{Kegunaan Teoritis}

Dengan penelitian ini di harapkan, akan memperoleh dan menambah pengetahuan peneliti mengenai teori-teori yang berhubungan dengan masalah internasional serta melatih kemampuan berpikir dan menganalisis suatu permasalahan.

\subsubsection{Kegunaan Praktis}

1. Sebagai dedikasi peneliti dalam memberikan sumbangsih pemikiran dan dapat dijadikan sebagai bahan referensi dan rujukan bagi mereka yang membutuhkan.

2. Sebagai bahan referensi.

3. Untuk memenuhi salah satu syarat akademik dalam menempuh ujian strata-1 (S1) pada Jurusan Hubungan Internasional Fakultas Ilmu Sosial dan Ilmu Politik di Universitas Komputer Indonesia

\section{Kajian Pustaka dan Kerangka}

\section{Pemikiran}

\subsection{Hubungan Bilateral}

Dalam Hubungan Internasional, kerjasama yang terjadi di antara dua

negara yang sifatnya saling menguntungkan secara umum dikenal dengan hubungan bilateral. Di dalam penelitian ini, peneliti menggunakan konsep bilateral untuk menggambarkan kejelasan didalam hubungan dua negara di dalam satu kawasan.(Goldstein 2003 :333).

Hubungan bilateral merupakan keadaan yang menggambarkan hubungan timbal balik antara kedua belah pihak yang terlibat, dan aktor utama dalam pelaksanaan hubungan bilateral itu adalah negara (Perwita dan Yani, 2005:28).

\subsubsection{Kerjasama Bilateral}

Hubungan bilateral adalah suatu hubungan politik, budaya dan ekonomi di antara dua negara. Kebanyakan hubungan internasional dilakukan secara bilateral. Misalnya perjanjian politik-ekonomi, pertukaran kedutaan besar, dan kunjungan antar negara. Alternatif dari hubungan bilateral adalah hubungan multilateral; yang melibatkan banyak negara, dan unilateral; ketika satu negara berlaku semaunya sendiri (freewill).

Perjanjian bilateral bersifat khusus (treaty contract) karena hanya mengatur hal-hal yang menyangkut kepentingan kedua negara saja. Oleh karena itu, perjanjian bilateral bersifat tertutup. Artinya tertutup kemungkinan bagi negara lain untuk turut serta dalam perjanjian tersebut.

\subsubsection{Konsep Sengketa dalam Hubungan Internasional}

Pada umumnya hukum internasional membedakan sengketa internasional atas sengketa yang bersifat politik dan sengketa yang bersifat hukum. Sengketa politik ialah sengketa di mana suatu negara mendasarkan tuntutannya atas 
pertimbangan non-yuridik, misalnya atas dasar politik atau kepentingan nasional lainnya. Atas sengketa yang tidak bersifat hukum ini, penyelesaiannya adalah secara politik. Sedangkan sengketa hukum ialah sengketa dimana suatu negara mendasarkan sengketa atau tuntutannya atas ketentuan-ketentuan yang terdapat di dalam suatu perjanjian atau yang tidak boleh diakui oleh Hukum Internasional (Boer Mauna, 2000:188)

Menurut Rachmadi Usman, sengketa merupakan konflik yang berkelanjutan atau berkepanjangan dan belum mendapat penyelesaian (1995:95).

\subsection{Kerjasama Bilateral}

Hubungan bilateral adalah suatu hubungan politik, budaya dan ekonomi di antara dua negara. Kebanyakan hubungan internasional dilakukan secara bilateral. Misalnya perjanjian politik-ekonomi,

pertukaran kedutaan besar, dan kunjungan antar negara. Alternatif dari hubungan bilateral adalah hubungan multilateral; yang melibatkan banyak negara, dan unilateral; ketika satu negara berlaku semaunya sendiri (freewill).

Perjanjian bilateral bersifat khusus (treaty contract) karena hanya mengatur hal-hal yang menyangkut kepentingan kedua negara saja. Oleh karena itu, perjanjian bilateral bersifat tertutup. Artinya tertutup kemungkinan bagi negara lain untuk turut serta dalam perjanjian tersebut.

\subsection{Perjanjian Internasional}

Sebelum tahun 1969 hukum perjanjian internasional terdiri dari kaidah-kaidah hukum kebiasaan internasional. Kaidah-kaidah ini untuk sebagian besar telah dikondifikasikan dan disusun kembali dalam Konvensi Wina tentang Hukum Peejanjian Internasional (Vienna Convention on the Law of Treaties), yang dibentuk pada tanggal 23 Mei 1969 dan mulai berlaku pada tanggal 27 Januari 1980 menyusul masuknya 35 ratifikasi atau aksesi sebagaimana disyaratkan oleh Pasal 84 Konvensi.

Sesuai dengan definisi yang dipakai dalm Pasal 2 Konvensi, sebuah Perjanjian internasional dapat didefinisikan sebagai : Suatu perjanjian dimana dua negara atau lebih mengadakan hubungan antara mereka yang diatur oleh hukum interasional. Memang istilah traktat dapat dianggap sebagai nama umum dalam

hukum internasional dan dapat mencangkup perjanjian antara organisasiorganisasi internasional disatu pihak dan sebuah negara dipihak lain meskipun harus diingat bahwa ketentuan-ketentuan Konvensi Wina tidak berlaku terhadap instrumen lain tersebut, melainkan menunjuk pada perjanjian antara negaranegara yang dibuat dalam bentuk tertulis. Di lingkungan internasional, perjanjian itulah yang digunakan untuk hampir setiap jenis perbuatan hukum atau transaksi, mulai dari persetujuan yang sifatnya bilateral semata-mata antara negara-negara sampai suatu perjanjian yang paling pokok seperti instrumen konstitusi multilateral sebuah organisasi internasional. Hampir dalam semua

kasus, tujuan sebuah perjanjian internasional adalah untuk membebankan kewajiban-kewajiban yang mengikat terhadap negara-negara pesertanya.

Tahap-tahap dalam pembuatan perjanjian internasional adalah:

1) Perundingan (negotiation)

2) Penandatanganan (signature) 
3) Ratifikasi (ratification)

b. Bentuk - bentuk perjanjian internasional adalah:

1) Traktat

2) Konvensi

3) Protokol

4) Persetujuan

Persetujuan (agreement) sifatnya kurang resmi dibanding traktat dan konvensi, dan umumnya tidak dilakukan oleh kepala-kepala negara. Biasanya bentuk ini dipakai untuk persetujuan persetujuan yang ruang lingkupnya lebih sempit dan pihak-pihak yang terlibat lebih sedikit dibanding ini juga hanya digunakan untuk persetujuan persetujuan yang sifatnya teknis dan administratif. Pada umumnya agreement tidak memerlukan ratifikasi dan berlaku sesudah dilakukan exchange of notes.

5) Arrangemen

6) Proses Verbal

7) Statuta

8) Deklarasi

9) Modus Vivendi

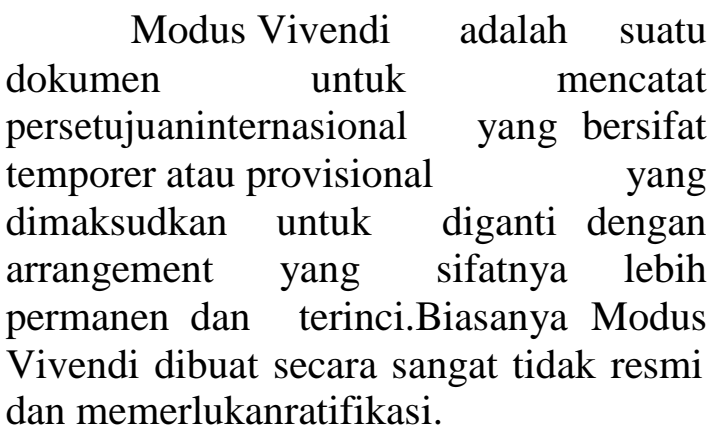

10) Pertukaran Nota atau Surat

11) Ketentuan Penutupan (Final Act)

12) Ketentuan Umum (Rudy, 2002:123-135).

\subsection{Ekonomi Politik Internasional}

Pada dekade 1970-an sejumlah pemikir Hubungan Internasional (HI) mulai memikirkan bagaimana negara negara yang selalu didorong nafsu berperang, pada waktu yang sama tetap berkeinginan untuk tetap menjalin

kerjasama dengan negara lain (Hermawan, 2005:5).

Para pemikir tersebut (yaitu, menginginkan negara-negara yang selalu didorong nafsu berperang untuk tetap melakukan kerja sama dengan negara lain), sebagaimana yang dijelaskan Hadiwinata, diantaranya adalah Kohane dan Nye, mencoba untuk menggambarkan bagaimana saling ketergantungan di bidang ekonomi telah mendorong negara-negara untuk tetap menjalin kerja sama. Kemudian, Robert Gilpin mencoba mengidentifikasi keberadaan perusahaan multinational sebagai pelaku penting dalam mendorong negara-negara untuk terlibat dalam kerja sama ekonomi. Melalui aktivitas perusahaan - perusahaan multinasional, modal, barang dan jasa dapat saling dipertukarkan melewati batasbatas negara dalam waktu relatif singkat sehingga dengan sendirinya meningkatkan kerja sama ekonomi antarnegara. Sejak saat itu, menurut Hadiwinata ilmu ekonomi mulai mempengaruhi studi Hubungan Internasional (Hermawan, 2007:6).

Selama negara-negara di dunia menjadi saling bergantung dalam bidang satu sama lain, mereka membutuhkan peraturan untuk mengatur hubungan ekonomi internasional, yaitu perjanjian multilateral dan organisasi internasional (Rudy, 2005:75).

Menurut T May Rudy, organisasi ekonomi internasional adalah semua organisasi dari suatu dasar antarpemerintah yang berhubungan 
dalam hubungan ekonomi keuangan danpembiayaan atau hal lain yang langsung mempunyai pengaruh pada hubungan tersebut (Rudy, 2005:76).

Konsep - konsep dan teori yang dipandang paling banyak diperbincangkan dalam ekonomi politik internasional pada bentang kontemporer yakni politik ekonomi, keterbelakangan, ketergantungan, saling ketergantungan, rejim internasional, pembangunan ekonomi, ekonomi kesejahteraan, dan teori ekonomi politik kontemporer lainnya.

Secara Umum Ekonomi-Politik Internasional merupakan studi yang memperlajari keerhubungan antara ekonomi internasional dengan politik internasional yang muncul akibat berkembanganya masalah-masalah yang terjadi dalam sistem internasional (Perwita dan Yani, 2005:75). Sehingga secara empirik, tingkat saling ketergantungan dalam masyarakat internasional yang semakin tinggi sebagai akibat proses transnasionalisme dalam ekonomi yang melewati batas negara seperti peningkatan perdagangan, proses globalisasi dan terciptanya kelompok ekonomi regional telah menjadikan suatu kondisi dimana tidak ada lagi suatu kebijakan ekonomi politik nasional yang bersifat domestik. (Perwita dan Yani, 2005: 77)

Konfigurasi pendekatan ekonomi politik internasional adalah tidak tunggal (monodisiplin), artinya bahwa implementasi alat-alat analisisnya dapat dilihat pada sejumlah teori dan konsepkonsep yang mendasari substansi ekonomi politik, seperti interdepedensi, depedensi,keterbelakangan,pertumbuhan, perkembangan, pembangunan ekonomi sosial, sistem-sistem ekonomi dan termasuk juga persoalan power politics, realisme dan idealisme, linier dan strukturalis internasional, globalisasi, atau regionalisme, dan lain-lain (Ikbar, 2002:21).

Secara umum, akan dijelaskan pengertian ekonomi politik terlebih dahulu sebelum menjelaskan defenisi/pengertian ekonomi politik internasional itu sendiri. Lord Robbin menjelaskan bahwa: Ekonomi politik dapat mengandung dua versi. Pertama, ialah versi ekonomi klasik yang memberi pengertian ekonomi politik sebagai suatu kesatuan menyeluruh dari suatu pembahasan, sejak dari ilmu ekonomi (murni, teori) itu sendiri (economics science) samapi dengan teori-teori tentang kebijakan ekonomi (theory of economics policy) yang meliputi analisis dari bekerjanya keuangan negara. Kedua, ekonomi politik versi modern yaitu ekonomi politik yang membahas bagaimana sistem ekonomi itu bekerja.

Namun demikian, ia bukanlah sciencetific economics yang merupakan himpunan dari value free generalization tentang cara-cara sistem ekonomi itu bekerja. Ekonomi politik di sini membicarakan prinsip-prinsip umum dalam bidang ekonomi (Ikbar, 2002:17).

\subsection{Perdagangan Internasional}

Perdagangan antarnegara atau lebih dikenal dengan perdagangan internasional, sebenarnya sudah ada sejak zaman dahulu namun dalam ruang lingkup dan jumlah yang terbatas sehingga pemenuhan kebutuhan dalam negeri yang tidak dapat diproduksi, mereka melakukan transaksi dengan cara barter (pertukaran barang dengan barang lainnya yang dibutuhkan oleh kedua belah pihak, dimana masing-masing negara tidak dapat memproduksi barang tersebut untuk kebutuhannya sendiri). Ini terjadi karena setiap negara dengan negara mitra dagangnya mempunyai beberapa perbedaan diantaranya 
perbedaan kandungan sumber daya alam, iklim, penduduk, sumber daya manusia, dan lain sebagainya. Dari perbedaan tersebut diatas, maka atas dasar kebutuhan akan barang lain yang saling menguntungkan sehingga terjadilah proses pertukaran yang dalam skala yang luas dikenal sebagai perdagangan internasional.

Adapun sebab - sebab umum yang mendorong terjadinya perdagangan internasional adalah sebagai berikut :

1. Sumber daya alam (natural resources)

2. Sumber daya modal (capital resources)

3. Tenaga kerja (human resources)

4. Teknologi.

Perdagangan internasional yang semakin meluas akan menimbulkan proses liberalisasi perdagangan kepada negara di sekitarnya. Proses ini menunjukkan suatu arah perekonomian yang bebas menurut paham liberalisme. Proses tersebut berimplikasi pada perekonomian suatu negara. Implikasi tersebut adalah :

1. Liberalisasi arus barang menuntut pengurangan hambatan tarif, bea, proteksi serta hambatan local content. Hambatan local content merupakan ketentuan hukum yang mewajibkan produk dalam negeri harus menggunakan komponen yang diproduksi dari dalam negeri.

2. Bertambahnya kapasitas produksi di seluruh dunia. Misalnya berkembangnya industrialisasi di berbagai lokasi di dunia dan berkembangnya perekonomian Negara Eropa Timur, India, China dan negara-negara Asia yang menjadi The Newly Industrializing Countries (NICs).
3. Kemajuan teknologi dalam bentuk revolusi teknologi informasi mengatasi batasan mobilitas akibat batas-batas negara dan berupa penurunan biaya transaksi dan komunikasi. Peningkatan Investasi Langsung Asing / Foreign Direct Investment (FDI). Sejarah mencatat, negara yang tidak mempunyai tabungan dalam negeri yang cukup untuk membiayai pertumbuhan ekonomi, umumnya menutup kesenjangan pembiayaan dengan mencari sumber-sumber dari luar negeri. Dengan demikian tidak heran apabila, mengalir arus modal dari negara industri ke negara berkembang. Arus modal ini dibagi menjadi dua, yakni arus modal yang tidak harus dibayar kembali dan yang harus dibayar kembali. Arus modal yang harus dibayar kembali diklasifikasikan menurut sumber arus modal tersebut, yakni dari sektor pemerintah dan sektor swasta negara maju kepada sektor yang sama di negara berkembang. Arus modal yang masuk dari sektor pemerintah sebagian besar berupa tabungan resmi yang bersifat konsesional dan sering disebut sebagai bantuan luar negeri,

walaupun demikian karena sifatnya tetap harus dikembalikan umumnya disebut sebagai utang luar negeri. Sedangkan arus modal yang masuk dari sektor swasta dapat berupa investasi langsung baik dari individu maupun TNC (Transnational

Coorporations), investasi portofolio dan kredit ekspor (Kuncoro, 2003:247-248). 
Penanaman investasi asing langsung merupakan bentuk yang berpengaruh bagi negara berkembang, karena biasanya disertai teknologi maju dan akses ke pasarinternasional dalam satu paket. Sebagian besar investasi asing langsung dilaksanakan oleh TNC (Bahagijo, 2006: 29).

\subsection{Bisnis Internasional}

Bisnis Internasional merupakan suatu bidang kajian yang membahas tentang fenomena hubungan ekonomi internasional dimana negara dan aktor non-negara terlibat dalam sebuah kegiatan transaksi bisnis antar Negara (Sugeng, 2002:26).

Aspek penting dalam transaksi ekonomi atau bisnis antar bangsa adalah para pelaku bisnis yang membentuk berbagai jaringan distribusi untuk

mentransfer komoditi dari wilayahsurplusproduksi ke daerah-daerah minus produksi (Sugeng, 2002: 34).

Dalam kompetisi antar pelaku bisnis kontemporer pelaku utama bisnis internasional adalah perusahaanperusahaan yang bergerak di berbagai bidang (jasa dan komoditas) dan bahkan beroperasi melintasi batas-batas negara. Di dalam melakukan aktifitas bisnisnya, perusahaan pada umumnya mengemban dua macam misi: (1) penguasaan pangsa pasar bagi produk - produk yang dihasilkannya dan (2) mengemangkan aktifitas yang dapat memaksimalisasi perolehan profit atau keuntungan. Penguasaan pangsa pasar merupakan citacita hampir setiap perusahaan yang pada dasarnya bersedia melakukan apa saja sejak pengenalan produk baru (Sugeng, 2002:36).

Menurut Bob Sugeng Hadiwinata dalam memberikan sebuah penilaian tentang eksplanasi terhadap suatu pelaku bisnis internasionalharus dilihat pada (1) unit analisisnya (individu, komunitas, organisasi, negara, asosiasi regional atau gabungan antara berbagai aktor. (2) tingkat analisisnya (mikro, mezzo atau makro yang juga identik dengan lokal, nasional atau internasional, keterkaitan antara variabel- variabelnya (independen atau dependen) (4) regularitasnya, dengan melihat apakah ada suatu pola tertentu yang berulang, (5) dengan melihat apakah dapat melakukan suatu generalisasi terhadap suatu pola tertentu, serta (6) memprediksi konsekuensi- konsekuensi yang mungkin ditimbulkan oleh suatu fenomena tertentu (Sugeng, 2002: 43).

Keberhasilan yang dicapai oleh perusahaan sebagai pelaku kegiatan bisnis internasonal tidak lepas dari faktor penguasaan pasar dalam menunjang produksi (Sugeng, 2002: 45).

\subsection{Politik Luar Negeri}

Pada dasarnya tujuan utama studi Hubungan Internasional adalah mempelajari perilaku internasional, yaitu perilaku para aktor, baik negara maupun non-negara, dan interaksinya dalam arena internasional. Maka, dalam melaksanakan hubungan atau interaksi dengan negaranegara lain, dalam tujuannya untuk dapat memenuhi berbagai kepentingan nasionalnya, suatu negara akan merumuskan berbagai kebutuhannya tersebut dalam suatu formula kebijakan yang dinamakan politik luar negeri. Dalam proses pembuatan kebijakan luar negeri, terdapat beberapa langkah yang harus diperhatikan yaitu:

1. Menjabarkan pertimbangan kepentingan nasional kedalam bentuk tujuan dan sasaran yang spesifik.

2. Menetapkan faktor situasional dilingkungan domestic dan 
internasional yang berkaitan dengan tujuan kebijaksanaan luar negeri.

3. Menganalisis kapabilitas nasional untuk menjangkau hasil yang dikehendaki.

4. Mengembangkan perencanaan atau strategi untuk memakai

kapabilitas nasional dalam menanggulangi variable tertentu sehingga mencapai tujuan yang telah ditetapkan.

5. Melaksanakan tindakan yang diperlukan.

6. Secara periodik meninjau dan melakukanevaluasi

perkembangan yang telah berlangsung dalam menjangkau tujuan atau hasil yang dikehendaki. (Perwita dan Yani, 2005:50).

\subsection{Teori Investasi}

Pengertian investasi adalah pengeluaran-pengeluaran yang ditujukan untuk meningkatkan atau mempertahankan persediaan barang modal (capital stock) terdiri dari pabrik, mesin kantor, dan produk-produk tahan lama lainnya (Dornbusch danFischer, 2004).

Investasi yang lazim disebut dengan istilah penanaman modal atau pembentukan modal, menurut Sukirno (2002) adalah, "Merupakan komponen

kedua yang menentukan tingkat pengeluaran agregat". Menurut Tambunan (2001) di dalam neraca nasional atau struktur PDB menurut penggunaannya, investasi didefinisikan sebagai pembentukan modal/kapital tetap domestik (domestic fixed capital formation). Investasi dapat dibedakan antara investasi bruto (pembentukan modal tetap domestic bruto) dan investasi netto (pembentukan modal tetap domestik netto).
Menurut definisi dari Badan Pusat Statistik (BPS, 2007), pembentukan modal tetap adalah pengeluaran untuk pengadaan, pembuatan, atau pembelian barang- barang modal baru (bukan barang-barang konsumsi) baik dari dalam negeri maupun import, termasuk barang modal bekas dari luar negeri. Pembentukan modal tetap yang dicakup hanyalah yang dilakukan oleh sektorsektor ekonomi di dalam negeri (domestik). Nopirin (2000) ìInvestasi merupakan salah satu komponen yang penting dalam PDB. Selanjutnya Nopirin (2000), Faktor yang mempengaruhi investasi diantaranya adalah tingkat

bunga, penyusutan, kebijaksanaan pemerintah, perkiraan tentang penjualan dan kebijaksanaan ekonomi. Tingkat kegiatan perekonomian ditentukan oleh besaran-besarannya pengeluaran agregat yang wujud dalam perekonomian. Dan dalam perekonomian pengeluaran agregat itu sendiri dari empat jenis pengeluaran yaitu: pengeluaran konsumsi rumah tangga, investasi oleh perusahaan perusahaan, pengeluaran pemerintah dan ekspor. Dari kenyataan itu dapatlah disimpulkan bahwa naik turunnya tingkat kegiatan ekonomi adalah ditimbulkan

oleh perusahaan-perusahaan dari masingmasing atau gabungan factor faktor tersebut. Pada setiap moment, persediaan modal adalah determinan output perekonomian yang penting, karena persediaan modal bisa berubah sepanjang waktu, dan perubahan itu bisa mengarah ke pertumbuhan ekonomi.

Biasanya, terdapat dua kekuatan yang mempengaruhi persediaan modal: investasi dan depresiasi. Investasi mengacu pada pengeluaran untuk perluasan usaha dan peralatan baru, dan hal itu menyebabkan persediaan modal bertambah.Depresiasi mengacu pada penggunaan modal, dan hal itu menyebabkan persediaan modal 
berkurang (Mankiw, 2006). Untuk keperluan statistik, istilah investasi asing kita gunakan definisi dari IMF Balance of Payment Manual (edisi ke empat), yang juga digunakan oleh Bank Indonesia. Definisi tersebut adalah: ìnvestasi langsung mengacu pada investasi untuk memperoleh manfaat yang cukup lama dalam kegiatan perusahaan dalam suatu perekonomian di luar tempat penanaman modal tersebut, sementara tujuan

penanaman modal adalah untuk memperoleh pengaruh secara efektif dalam pengelolaan perusahaan tersebutî. Istilah manfaat yang cukup lamaî tersebut merupakan investasi yang pengelolaannya memerlukan sedikit pengawasan. pembatasan kuantitas juga mulai merambah pada pokok pikiran mengenai jasa keungan, isu hukum persaingan usaha, International Property Rights, hak buruh, perlindungan investasi dan perlindungan lingkungan. Penanaman modal asing lebih menjamin dalam kelangsungan pembanguanan dibandingkan dengan pinjaman luar negeri. Dengan adanya investasi asing, di Negara tesebut akan mendapat keuntungan dalam teknologi, transfer aset dan ketrampilan, transfer keahlian manajemen, dan resiko usaha relatif kecil dan lebih profitable. Perkembangan teknologi sudah dirasakan di Indonesia akibat dari sejumlah perusahaan asing, kebanyakan mereka perusahaan multinasional besar, yang sudah menanam modal di pasar Indonesia. Perusahaan ini sudah menyokong banyak dalam pengembangan sumber daya negeri, membangun infrastruktur, menetapkan fasilitas pabrik untuk mengekspor dan/atau menyediakan produk dan jasa untuk pasar yang domestik itu.

\section{Metode Penelitian}

Untuk melakukan sebuah penelitian, diperlukan sebuah desain atau rancangan yang berisi rumusan tentang objek yang akan diteliti. Metode penelitian yang digunakan penulis dalam penelitian ini adalah menggunakan metode penelitian deskriptif analisis kualitatif. Merujuk pada permasalahan yang diangkat serta variable yang tersedia, maka peneliti

hanya melakukan analisa data berdasarkan data-data serta informasi yang dikeluarkan The United State Indonesia Society (USINDO) yang menjembatani kemitraan Indonesia dan Amerika Serikat ataupun Pemerintah Amerika dan diimplementasikan dengan teori - teori dalam kajian Hubungan Internasional.

\section{Hasil dan Pembahasan}

KoreaSelatandanJepang

merupakan kedua negara yang letaknya berdampingan. Keduanya kerap kali terlihat dalam hubungan, baik dalam segi positif maupun negatif. Dalam segi negatif, konflik kerap kali mewarnai dinamika hubungan keduanya dimulainya dari yang terjadi puluhan tahun silam sampai kasus yang hingga kini belum dapat terselesaikan. Perebutan suatu

kepulauan oleh beberapa negara memang menjadi masalah yang rumit. Kasus ini kembali muncul ke permukaan pada 10 Agustus 2012 dengan kunjungan

Lee Myung Bak ke pulau Dokdo/Takeshima. Kunjungan ini merupakan kali pertama seorang Presiden Korea Selatan menginjakan kaki di atas wilayah sengketa tersebut (Diakses tanggal 5 Juli 2015 melalui http://www.bbc.com/news/world-asia- 
20038776).

Pihak kepresidenan mengatakan bahwa kunjungan Lee Myung Bak ini merupakan tanggapan Korea Selatan atas tindakan Jepang yang semakin mengkampanyekan bahwa pulau tersebut adalah milik mereka (Diakses tanggal 5

Juli 2015 melalui

http://www.nytimes.com/2012/08/11/wor ld/asia/south-koreans-visit-to-disputedislets-angers-japan.html? r=0).

\subsection{Sejarah Sebelum Perang Dunia II}

Pada tahun 1737, ahli geografi Prancis D'Anville's, Peta dari Korea menandai Dokdo (Usando) merupakan bagian dari wilayah Korea. Ulengdo dan Dokdo digariskan sangat dekat laut Timur Korea Selatan. (Diakses tanggal 1 Juli 2015 melalui http://en.dokdo.go.kr/pages/sub02/page.h tml $? \mathrm{mc}=0095 \& \mathrm{start}=0 \&$ categoryCode $=0$ 03).

Era Tokugawa runtuh pada Januari 1868, dan masa Restorasi Meiji mulai terbentuk, perdana menteri pemerintahan yang baru mengirimkan pejabat-pejabat tinggi dari kantor urusan luar negeri ke Joseon untuk menyelisiki rahasia atas 14 masalah pada bulan Desember 1869. Saat itu terdapat perintah investigasi (suatu keadaan dimana Ulengdo dan Dokdo termasuk wilayah Joseon) diantara mereka. (Diakses tanggal 1 Juli 2015 melalui http://www.dokdotakeshima.com/).

\subsection{Periode Setelah Perang Dunia II}

Saat Jepang menyerah pada sekutu tanggal 15 Agustus 1945, sekutu membuat pemerintahan tinggi di Tokyo dan mulai mengembalikan wilayahnya kolonial yang dimiliki Jepang kepada pemilik asalnya. Pada tanggal 29 Januari 1946, pemerintahan tinggi mengeluarkan edaran militer No. 677 SCAPIN dan mengembalikan Jejudo, Ulengdo dan Dokdo (Liancourt Rocks) kepada Korea Selatan (Diakses tanggal 1 Juli 2015 melalui http://www.dokdotakeshima.com/a-timeline-of-u-s-actiondokdo.html).

Korea membentuk pemerintah pada tanggal 15 Agustus 1945 dan mengambil alih Peninsula Korea, Dokdo dari semua pulau lepas pantai sebagai wilayahnya dari sekutu, begitu pula dengan Korea diakui juga daerah teritorialnya denah kekuasaannya oleh PBB secara resmi pada tanggal 12 Desember 1948. Sampai akhirnya pada tanggal 22 Juni 1965, ketegangan antara kedua Korea Selatan dan Jepang diredam dengan ditandatanganinya Traktat Hubungan Dasar (Treaty on Basic Relations) di Tokyo (Man,2000).

Hallyu muncul seiring dengan meningkatnya minat publik pada kesenian pop dan tradisional Korea Selatan di Asia, Eropa, Timur Tengah, dan Amerika (Korean Culture and Information Service,2011;10-11). Pada

Desember 2010, CNN Amerika melaporkan bahwa Korean Wave telah menyapu seluruh Asia, dan bahwa Korea Selatan telah menjadi "Hollywood of the East" (Korean Culture and Information Service, 2011;14).

Istilah "Hallyu" pertama kali diperkenalkan oleh media Cina untuk menggambarkan hiburan Korea yang terkenal sejak tahun 1990-an. Hallyu pertama kali masuk ke negara Cina dan Jepang yang merupakan negara-negara tetangga Korea Selatan, kemudian menyebar luas ke Asia Tenggara bahkan 
kini sampai ke Timur Tengah, Eropa, dan Amerika (Korean Culture and Information Service,2011;10-11).

Faktor lain yang memicu perkembangan Hallyu adalah musik, musik yang berasal dari Korea Selatan dipopulerkan dengan sebutan K-pop. Kpop (singkatan dari Korean Pop) (Lie,2012:339). K-pop mulai berkembang pada akhir tahun 90-an saat Channel V, yang merupakan sebuah stasiun televisi musik berbasis regional, menampilkan video musik dari lagu pop asal Korea Selatan, sehingga membentuk kelompok penggemar (fan base) K-pop besar di Asia.

Pada tahun 2012, perkembangan Hallyu di Jepang mengalami hambatan karena kasus sengketa pulau Dokdo/Takeshima antara Korea Selatan dan Jepang pada 10 Agustus 2012 dengan kunjungan Lee Myung Bak ke pulau

Dokdo/Takeshima. Kunjungan ini merupakan kali pertama seorang Presiden Korea Selatan menginjakan kaki di atas wilayah sengketa tersebut (Diakses

tanggal 5 Juli 2015 melalui http://www.bbc.com/ news/world-asia20038776). Pihak kepreside nan mengatakan bahwa kunjungan Lee Myung Bak ini merupakan tanggapan Korea Selatan atas tindakan Jepang yang semakin mengkampanyekan bahwa pulau tersebut adalah milik mereka (Diakses

tanggal 5 Juli 2015 melalui http://www.nytimes.com/2012/08/11/wor ld/asia/south-koreans-visit-to-disput edislets-angers-

Setelah kegiatan "Swim to Dokdo" kegiatan berenang estafet ke pulau sengketa Dokdo/Takeshima yang dilakukan pada 15 Agustus 2012. Drama yang dibintangi aktor Korea Selatan Song Il Guk yaitu "A Man Called God" dan "Detectives in Trouble" diganti oleh stasiun televisi Jepang BS dan BS Nitpon ditahun yang sama setelah kegiatan "Swim to Dokdo" berakhir. Song Il Guk dengan puluhan perenang lainnya dalam proyek untuk memprotes klaim Jepang atas pulau Dokdo/Takeshima (Diakses tanggal 5 Juli 2015 melalui http://www.koreatimes.co.kr/www/news/ cultur e/2013/03/386_132238.html). Lebih lanjut lagi, wakil Mentri Luar Negeri Jepang, Tsuyoshi Yamaguchi mengumumkan, "Maafkan saya, tetapi mulai saat ini ia (Song Il Guk) akan sulit menjejakkan kakinya ke Jepang. Kurasa ini apa yang diinginkan oleh para warga negara Jepang." (Diakses pada tanggal 5 Juli 2015 melalui http://www.soompi.com/2012/08/29/polit ical-tension-over-dokdo-leads-to-

boycotting-hallyu-in-japan/).

Selanjutnya, girlband Korea Selatan Girls' Generation, atau di Jepang disebut Shojo Jidai, yang pada tahun 2008 menyanyikan lagu "Dokdo is Our Land" pada sesi latihan mereka sebelum konser dimulai untuk mengklaim pulau Dokdo/Takeshima adalah milik Korea Selatan. Boyband Korea Selatan BEAST pun mengatakan pada tahun 2010 "Dokdo adalah wilayah milik Korea Selatan" pada sebuah acara di Los Angeles Amerika Serikat. (Diakses tanggal 5 Juli 2015 melalui http://okepop.com/anti-hallyu-kembaliberkembang-karena-kasus-pulau-dokdo/).

Dalam tayangan "What's ON" di ArirangTV, Korea Selatan menginformasikan melalui segmen "Dokdo Blacklist" di televisi, Korea Selatan dan Jepang telah menyetujui program "Visa Waiver Agreement" (Memasuki negara tanpa visa selama 90 hari dari Korea Selatan ke Jepang atau dari Jepang ke Korea Selatan) (Diakses 
tanggal 5 Juli 2015 melalui http://www.mofa.go.kr/ENG/visa/applica tion/index.jsp?menu=m_40_10)

Seorang pejabat dari Partai Liberal Demokrat, salah satu partai politik utama di Jepang, telah meminta larangan segala sesuatu yang berhubungan dengan Korea Selatan dalam siaran pers pada 24 Agustus 2012. Pejabat ini mengatakan kepada wartawan surat kabar Tokyo Sports, "Kita perlu melarang Korean Wave, K-pop, semuanya yang berhubungan dengan Hallyu. Girls' Generation dan KARA pun disebutkan (Diakses tanggal 5 Juli 2015 melalui http://www.mtvk.com/blog-posts/japanwants-to-ban-korean-media-over-dokdoislands/).

Meskipun kepopuleran K-pop di Jepang, produk Korea Selatan seperti makanan, produk kecantikan, aksesorisaksesoris artis Korea Selatan, hubungan antara Jepang dan Korea Selatan tetap tegang belakangan ini. Dalam beberapa bulan terakhir, bagaimanapun, kelompok "Anti-Korea" semakin bertambah. dengan protes Anti-Korea yang terjadi lebih sering dan lebih banyak, terutama di daerah dimana tempat berkumpul dan tempat orang Korea Selatan tinggal di Jepang.

Pada tahun 2015, untuk pertama kalinya semenjak Hallyu Wave dilarang tampil di Jepang, Hallyu festival datang ke Jepang, festival ini bernama KCON ALL THINGS HALLYU. Festival ini diadakan di Saitama Super Arena di Jepang pada tanggal 22 April 2015. Festival ini menampilkan penyanyi idola Korea Selatan seperti BLOCK B, SISTAR, Infinite, GOT7, 2PM Jun.K, dll. Festival ini pun menjual aksesorisaksesoris artis idola Korea Selatan, makanan khas Korea seperti kimchi, dan memperkenalkan budaya Korea Selatan.
Festival ini dihadiri 15.000 penggemar (Diakses tanggal 5 Juli 2015 melaluittp://www.mtviggy.com/articles/k con-japan-2015-k-pop-j-pop-mynamesistar-infinite/).

\subsection{Arti Penting Jepang Bagi Hallyu}

Drama Winter Sonata yang dibintangi aktor Korea Selatan Bae Yong Jun telah menjadi simbol dari awal kepopuleran Hallyu di Jepang pada awal tahun 2003. Berikut adalah data elemen Hallyu yang paling favorit yang ada di Jepang:

Tabel 4.1 Elemen Hallyu terfavorit yang ada di Jepang

\begin{tabular}{|c|c|c|}
\hline $\begin{array}{c}\text { Drama Korea } \\
\text { Selatan }\end{array}$ & Aktor & Penyanyi idola \\
\hline Winter Sonata & Bae Yong Jun & TVXQ \\
\hline $\begin{array}{c}\text { Rooftop Prince } \\
\text { You're }\end{array}$ & Park Yoochun & KARA \\
\hline Beautiful & Jang Geun-suk & BIGBANG \\
\hline
\end{tabular}

Sumber: Winner of Hannryu $10^{\text {th }}$ Anniversary 2013 in Japan

(http://parksihoo4u.com/2013/10/19/pshranks-in-hanryu-final-results/)

Drama Winter Sonata yang dibintangi Bae Yong Jun tidak dapat dipungkiri adalah awal mula Hallyu berkembang di Jepang pada tahun 2003.

Arti penting Jepang terhadap Hallyu adalah karena Jepang pada tahun 2010 merupakan pasar musik terbesar di dunia setelah Amerika. Masyarakat Jepang menghabiskan lebih banyak uang untuk musik per orang daripada masyarakat lain di dunia, hampir 3 kali lebih dari masyarakat Amerika. Sekitar 82\% dari seluruh penjualan musik di Jepang adalah digital melalui Internet download 
(smartphone, tabel, dan komputer), sementara $18 \%$ melalui ponsel tradisional atau Keitai. Sekitar 53\% dari seluruh penjualan musik di Jepang adalah penjualan digital, sementara $47 \%$ adalah penjualan fisik (Diakses tanggal $10 \mathrm{Juli}$ 2015 melalui http://japanmusicmarketing.com/).

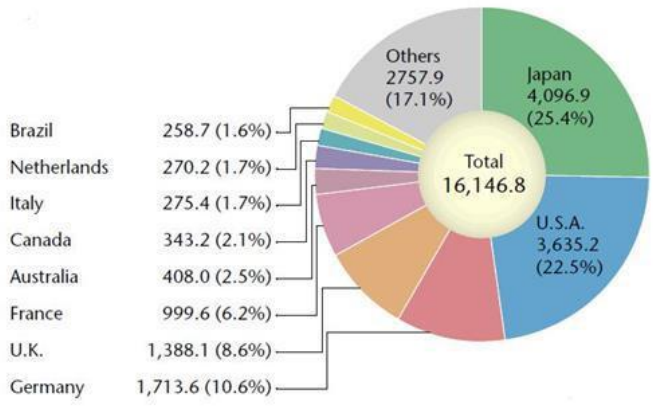

Diagram 4.1 Saham Global Penjualan Rekaman Musik. Sumber : Recording Industry Association in Japan (RIAJ) 2012 Yearbook di Dunia Tahun 2010.

\subsection{Data Penelitian}

Dalam sebuah penelitian subyek penelitian atau informan sangatlah penting bahkan kunci utama.

Dalam penelitian yang dilakukan peneliti telah memperoleh data dari berbagai sumber yang dilakukan melalui studi pustaka berupa tulisan atau artikel, penulusan data online berupa data yang berasal dari situs-situs tertentu, metode dokumentasi berupa catatan, transkrip,

buku, surat dan sebagainya dan wawancara dengan melakukan studi lapangan ke lembaga-lembaga terkait. Untuk menguji validitas dan realibilitas data yang telah diperoleh peneliti mengkases situs-situs resmi pemerintah dan lembaga-lembaga serta mengkonfirmasi ke lembaga-lembaga terkait yang mempunyai keterkaitan dengan penelitian yang dilakukan, yaitu Kedutaan Besar Jepang.

Dalam menguji Valibilitas dan Reabilitas mengenai data-data yang diperoleh oleh peneliti berupa sejarah sengketa pulau Dokdo/Takeshima antara Korea Selatan dan Jepang, peneliti melakukan studi literature dengan mengunjungi

Korean Cultural Center dan Japan Foundation, untuk mencari tahu sejarah pulau Dokdo/Takeshima dari masingmasing negara, dan mencari data

tentang perkembangan Hallyu dari dulu sampai sekarang. penelitipun melakukan konfirmasi dengan cara mengakses situs resmi pemerintahan Korea Selatan dan situs resmi pemerintahan Jepang yang dikelola langsung oleh pemerintah dan semua informasi dipublikasikan secara resmi oleh pemerintah melalui situs tersebut yang sudah di uji kebenarannya serta dapat dipertanggungjawabkan maka situs tersebut bisa dijadikan sebagai salah satu cara untuk menguji data yang telah diperoleh.

Data-data berupa sejarah sengketa pulau Dokdo/Takeshima antara Korea Selatan dan Jepang, sejarah pulau Dokdo dari Korea Selatan, sejarah pulau Takeshima dari Jepang, sejarah Hallyu, sejarah perkembangan Hallyu di Jepang, peneliti dalam melakukan uji validitas dan reabilitas dilakukan dengan cara

melakukan konfirmasi melalui wawancara dan studilapanganke Kedutaan Besar Jepang untuk Indonesia, Korean Cultural Center, dan Japan Foundation, dan perpustakaan LIPI untuk menguji data yang diperoleh.

Untuk menguji validitas dan reabilitas data tersebut peneliti melakukan konfirmasi melalui wawancara. Salah satu data yang diperoleh peneliti tentang dampak 
perkembangan Hallyu di Jepang pasca memanasnya kembali sengketa pulau Dokdo/Takeshima Korea Selatan-Jepang melakukan wawancara di Kedutaan Besar Jepang, menurut Ibu Ayako Masuda dari Bagian Informasi dan Kebudayaan Kedutaan Besar Jepang di Indonesia menyatakan bahwa akhir-akhir ini hubungan antara Jepang dan Korea Selatan kurang baik.

Data lain yang diperoleh peneliti adalah Sejarah-sejarah Pengakuan pulau Dokdo (Sebutan bagi Korea Selatan) dan pulau Takeshima (Sebutan bagi

Jepang) yang peneliti peroleh dari perpustakaan Korean Cultural Center dan perpustakaan the Japan Foundation.

\subsection{Hambatan Terhadap Perkembangan Hallyu di Jepang Pasca Kembali Memanasnya Sengketa Korea Selatan dan Jepang Pada Tahun 2012}

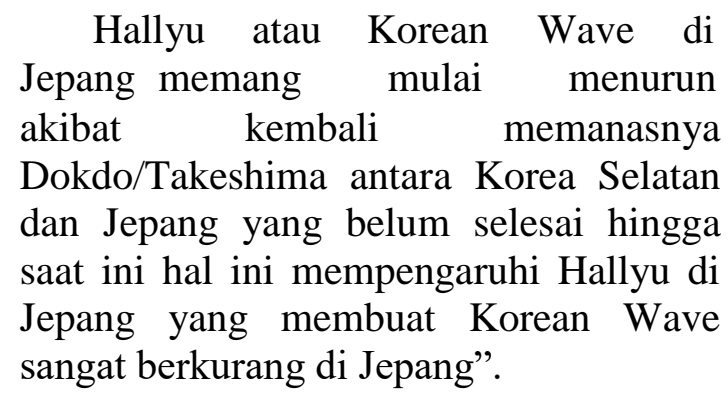

Korea Selatan telah menggunakan Hallyu sebagai soft power dari tahun 1999, Jepang juga tahu persis bahwa Hallyu itu salah satu alat diplomasi yang di andalkan Korea Selatan pada saat ini selain teknologi.

Ketertarikan pengguna internet Jepang terhadap Hallyu pun berkurang semenjak memanasnya kembali sengketa pulau Dokdo/Takeshima antara Korea Selatan dan Jepang. Hal ini dapat dilihat dari gambaran grafik di bawah ini:

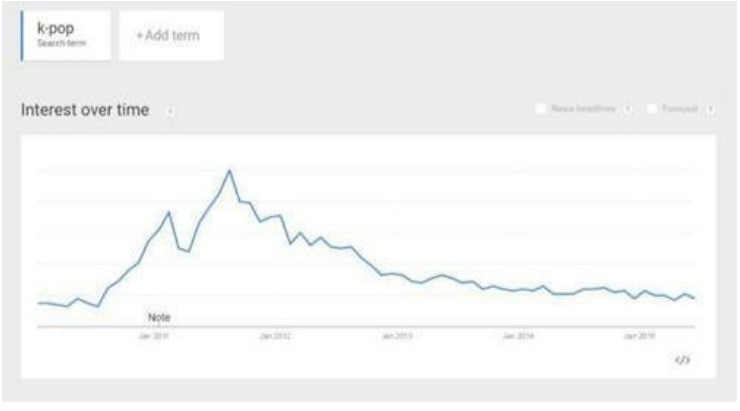

Gambar 4.3 Grafik penggunaan internet terhadap pencarian mengenai K-pop di Jepang Januari 2010 - Juni 2015 (Sumber: Google Trends (https://www.google.com/trends)

Data ini menjelaskan bahwa ada ketertarikan masyarakat terhadap Korean Music (K-Pop), apakah itu musiknya, artikel, foto, data-data artis Korea Selatan. Dapat dilihat bahwa puncak ketertarikan pengguna internet Jepang terhadap K-pop di pertengahan tahun 2010 karena pada tahun 2010 adalah awal munculnya K-Pop di Jepang. K-pop berkembang cepat di Jepang dan memuncak pada pertengahan Agustus 2011. Terlihat ketertarikan terhadap Kpop berkurang pada tahun pertengahan 2012 di bulan Agustus, yaitu dimana kembali memanasnya permasalahan sengketa pulau Dokdo/Takeshima antara Korea Selatan dan Jepang, permasalahan ini sangat berpengaruh terhadap K-pop, terhitung dari akhir 2012 sampai Juni 2015 belum ada perkembangan yang signifikan terhadap K-pop di Jepang. Meskipun pada April 2015 diadakan Festival KCON di Jepang untuk pertama kalinya setelah pada tahun 2012 Hallyu dilarang tampil di media Jepang.Kunjungan Presiden Korea Selatan Lee Myung Bak ke pulau sengketa Dokdo/Takeshima pada tahun 2012 ini menjadi pemicu kemarahan bangsa Jepang yang mengakibatkan bertambahnya dan memuncaknya AntiKorea yang ada di Jepang. 


\subsection{Prospek dan Perkembangan Hallyu di Jepang Kedepannya}

Seperti yang kita ketahui, akibat sengketa pulau Dokdo/Takeshima antara Korea Selatan dan Jepang yang kembali memanas di tahun 2012 ini menghambat perkembangan Hallyu di Jepang. Bangsa Jepang memang memiliki kebencian khusus terhadap etnis Korea.

Terselenggaranya Festival KCON yang dilaksanakan pada bulan April tahun 2015 yang dikunjungi 15.000 penggemar yang dilaksanakan di Saitama Super Arena. Diharapkan dengan adanya Festival besar seperti ini, kedepannya Hallyu sedikit demi sedikit diterima kembali di Jepang.

\section{Kesimpulan dan Rekomendasi \\ 6.1 Kesimpulan}

Memanfaatkan kerangka konseptual dan teori yang telah disusun di kerangka pemikiran, data-data yang sudah dipaparkan maka dampak sengketa pulau Dokdo/Takeshima Korea Selatan-Jepang terhadap perkembangan Hallyu di Jepang adalah mengalami penurunan pasca memanasnya kembali sengketa pulau Dokdo/Takeshima Korea Selatan-Jepang pada tahun 2012.

Hallyu atau Korean Wave menjadi sebuah fenomena budaya baru atau pop culture yang tersebar luas di dunia termasuk di Jepang. Namun Korean Wave di Jepang ini mengalami hambatan dikarenakan kembali memanasnya hubungan Korea Selatan-Jepang karena permasalahan sengketa pulau Dokdo/Takeshima, yaitu kunjungan Presiden Korea Selatan Lee Myung-bak ke pulau sengketa pada tahun 2012. Sehingga fenomena Hallyu di Jepang mengalami hambatan yang dapat disimpulkan sebagai berikut:

Pertama, Kunjungan Presiden Korea Selatan Lee Myung-bak pada tahun 2012 ke pulau sengketa Dokdo/Takeshima menjadi pemicu terhambatnya perkembangan Hallyu di Jepang.

Kedua, permasalahan sengketa negara dapat memperburuk hubungan bilateral kedua negara, dalam kasus sengketa pulau Dokdo/Takeshima juga berdampak pada perkembangan budaya Hallyu di Jepang. Hal ini terlihat dengan berkurangnya animo masyarakat Jepang terhadap K-pop di Jepang.

Ketiga, persengketaan pulau ini berdampak terhadap perkembangan Hallyu di Jepang yang mengakibatkan Jepang melarang Hallyu melakukan aktivitas di Jepang setelah memanasnya kembali sengketa pulau Dokdo/Takeshima pada tahun 2012.

Keempat, Anti-Korea yang ada di Jepang memang sudah ada dari dulu sebelum Hallyu terkenal di Jepang, karena faktor sejarah kedua negara yang sangat buruk.

Kelima, Korea Selatan membuat statement bahwa Jepang melakukan "Dokdo Blacklist", yaitu dilarangnya artis dan idola Korea Selatan yang menyuarakan pendapat mereka tentang pulau sengketa Dokdo/Takeshima untuk memasuki wilayah Jepang

Keenam, terdapat beberapa dampak yang sangat terasa terhadap perkembangan Hallyu di Jepang akibat sengketa yang memanas kembali pada tahun 2012 ini yaitu, dilarangnya artis dan penyanyi asal Korea Selatan untuk beraktivitas di Jepang, dan tidak di 
undangnya penyanyi idola Korea Selatan ke konser akhir tahun Annual Kohaku pada akhir 2012.

Ketujuh, pada tahun 2010 Jepang merupakan pasar musik terbesar di dunia, itulah alasan mengapa Korea Selatan berusaha masuk ke pasar musik Jepang. K-pop telah berhasil masuk ke Jepang pada awal tahun 2010, dan Jepang pun menjadi pasar ekspor terbesar untuk Kpop dibandingkan negara-negara lain.

Terakhir, dengan berkurangnya minat masyarakat Jepang terhadap Hallyu, Korea Selatan pun tengah berupaya menghidupkan kembali budaya Hallyu di Jepang dengan menyelenggarakan festival KCON pada bulan April 2015 lalu, dengan kedatangan pengunjung tidak kurang dari 15.000.

\subsection{Rekomendasi}

Setelah melihat hasil penelitian ini, maka saran yang diberikan oleh peneliti terhadap dampak sengketa pulau Dokdo/Takeshima Korea Selatan-Jepang terhadap perkembangan Hallyu di Jepang adalah perkembangan Hallyu di Jepang adalah sebagai berikut:

Pertama, peneliti berharap kedepannya tidak ada lagi pemicu sengketa pulau Dokdo/Takeshima yang di angkat kembali baik dari Pemerintah Korea Selatan dan Pemerintah Jepang.

Kedua, diharapkan para peneliti dapat meneliti lebih jauh lagi, terutama mengenai prospek Hallyu di Jepang kedepannya seperti apa.

\section{Daftar Pustaka}

\section{Acuan dari buku:}

Adolf, Huala. 2004. Hukum Penyelesaian Sengketa Internasional. Jakarta: Sinar Grafika. Cultural Heritage Administration of Korea, 2009, Natural Heritage of Korea, Dokdo, Daejon, Natural Heritage Division.

Diamond, Louise dan McDonald, John. 1996. Multi-Track Diplomacy: A Systems Approach to Peace Third Edition. Oakwood Avenue, Kumarian Press

Djelantik, Sukawarsini. 2008. Diplomasi: Antara Teori Dan Praktik. Yogyakarta: Graha Ilmu

Goldstein, Joshua S. 2003. International Relations. Washington: Harper Collin College and Publisher

Korean Culture and Information Service (KOCIS). 2011. Korean Culture No. 2 K-POP A New Force in Pop Music. Ministry of Culture, Sports, and Tourism.

Ministry of Foreign Affairs of Japan. 2014. Takeshima Seeking a Solution based on Law and Dialogue. Tokyo: Ministry of Foreign Affairs of Japan

Perwita, Anak Agung Banyu, Yani ,Yanyan Mochamad. 2005. Pengantar Ilmu Hubungan Internasional. Bandung: Remaja Rosdakarya

Rana S, Khishan. 2002. Bilateral Diplomacy. New Delhi: Manas Publication

Shoelhi, Mohammad. 2011. Diplomasi:

PraktikKomunikasi Internasional. Bandung: Simbiosa Rekatama Media

Acuan artikel dalam buku publikasi:

Kementerian Perdagangan 2012

Kementerian Koordinator Perekonomian : 2011

Badan Pusat Statistik 2012 
Kementerian Koordinator Perekonomian 2011

\section{Acuan artikel dalam Jurnal:}

Claudya. 2009. Kerjasama Perdagangan

Bilateral. Economic World melalui http://buahpikir-claudyafisip09.web.unair.ac.id/kategori_i si $\quad-36739$ economic\%20 world.html [16/04/13].

Decy Arifinsjah. 2012. Kajian Kerjasama

Bilateral Indonesia - Amerika Serikat di Bidang Ekinomi dan Keuangan melalui http://www.fiskal.depkeu.go.id/20 10/adoku/2013\%5Ckajian\%5Cpkr b\%5CKajian_Kerja_Sma_Bilatera 1_RI-AS.pdf [20/6/2013]

\section{Acuan artikel dalam situs:}

U.SCompanies Export. 2012. Doing Business in Indonesia melalui http://export.gov/indonesia/doing bu sinessinindonesia/index.asp [15/05/2013]

Korean Celebrities Labeled

"Anti-Japanese"for Their Position on Dokdo. http://www.soompi.com/2012/08/ 29/8-korean-celebrities-labeledanti-japanese-for-their-positionon-dokdo/6/ [16/3/15]

Ahn Yong Bok and Dokdo Takeshima. http://www.dokdotakeshima.com/ahn-yong-bokdokdo-i.html [1/7/15]

Anti Hallyu kembali berkembang karena kasus Pulau Dokdo. http://okepop.com/anti-hallyukembali-berkembang-karenakasus-pulau-dokdo/ [5/7/15]

BoA - Main - Music Artist - Videos Full Biography. http://web.archive.org/web/20080 205124038/http://www.mtv.com/ music/artist/boa_3_/artist.jhtml\#bi o [3/7/15]

Boys Over Flowers Continues to Bloom in Korean http://koreatimes.co.kr/www/news /art/2009/02/135_39265.html [3/7/15]

Dokdo Profile and History. http://www.koreaaward.com/kor/d okdo_profil e [25/3/15]

Dong Bang Shin Ki to Hold Largest Fan Club Event in Japan Read more at:

http://tr.im/5UDA6 . http://www.hancinema.net/dongbang-shin-ki-to-hold-largest-fanclub-event-in-japan-41298.html

Element of The Korean Wave. http://www.bloomberg.com/photo /the-korean-wave-/331036.html [1/7/15]

Islan Dokdo. http://en.dokdo.go.kr/pages/sub02 /page.html?mc=0095\&start=0\&ca tegoryCode $=003$ [1/7/15]

Hayashi Shihei's 1785 Illustrated Survey of Three Countries Map. http://www.dokdotakeshima.com/1785-japanesemap-by-hiyoshi-shihei.html [1/7/15]

H.O.T Forever and god in Kpop (kpop history 2001). http://onehallyu.com/topic/54493hot-forever-and-god-in-kpopkpop-history-2001/ [3/7/15]

Kamus Besar Bahasa Indonesia Online. http://kbbi.web.id/ [20/4/15]

KARAJapan Tour Sold Out, Adds Additional 30,000 Seats . http://www.kpopstarz.com/articles /6848/20120 325/kara-membersjapan-tour-completely-soldout.html 
Top 20 Best Selling K-Pop Idol Albums of All Time? 'Rankings for Idols Since Debut'. http://www.kpopstarz.com/articles /20592/2013 0212/top-20-bestselling-k-pop-albums-of-all-timerankings-for-idols-sincedebut.htm [3/7/15] 